\title{
APPLICATION OF X-RAY TECHNIQUE IN NONDESTRUCTIVE EVALUATION OF EUCALYPT WOOD
}

\author{
M. Tomazello', S. Brazolin ${ }^{2}$, M. P. Chagas ${ }^{1}$, J. T. S. Oliveira ${ }^{3}$, A. W. Ballarin ${ }^{4}$, \\ C. A. Benjamin ${ }^{4}$ \\ ${ }^{1}$ Departamento de Ciências Florestais/USP, Piracicaba. SP; ${ }^{2}$ Instituto de Pesquisas Tecnológicas do \\ Estado de São Paulo, SP; ${ }^{3}$ Departamento de Ciências Florestais/UFES, Alegre. ES; ${ }^{4}$ Faculdade de \\ Ciências Agronômicas/UNESP, Botucatu. SP; Brasil
}

Corresponding author: mtomazel@esalq.usp.br

Received: 16.04.2007. Accepted: 26.05.2008.

\begin{abstract}
X-rays were initially used for the inspection of special-purpose wood pieces for quantitative evaluation of wood properties of different species. X-ray densitometry has had its use expanded in dendroclimatology of Picea engelmannii trees. Subsequent laboratories developed applications of X-ray densitometry for environmental, wood science and technology, and related areas. This paper describes the basic methodology of X-ray densitometry applied to the eucalypt wood analysis, as well as presenting the results of applications in three areas: (i) evaluation of wood biodegradation by white rot fungi, (ii) detection of sapwood and heartwood, and (iii) determination of the effect of management on wood properties. The wood decayed by white rot fungi was detected by X-ray densitometry with a decreasing wood density due to the biodegradation of cell wall components. The sapwood and heartwood of eucalypts were separated in response to the attenuation of X-rays, reflected by the wood anatomical structure and chemical composition. Also, in eucalypt trees after the application of irrigation and fertilizationirrigation characteristic wood density profiles were detected. In addition, the significant potential of X-ray densitometry for eucalypt wood research and analysis is discussed.
\end{abstract}

Keywords: Eucalypts, X-ray densitometry, sapwood, heartwood, density, white rot fungi.

\section{INTRODUCTION}

The earliest literature indicates that the use of the X-rays in the inspection of wood pieces began in the last century (Worschitz 1932, Fischer and Tasker 1940) through the qualitative wood evaluation for specific applications, such as tree poles, propellers, and other parts of airplanes in the examination for internal defects (knots, internal cracks, biological decomposition, wood boring insects, etc.). Later, several authors (Legrand 1946, Lenz, 1957, Jacquiot 1961, Polge 1963) applied X-ray densitometry for the quantitative evaluation of wood properties of different forest species and wood products. The use of X-ray densitometry was expanded by Parker (1971) when correlating climatic variables with density parameters of annual tree-rings of Picea engelmannii. Subsequently, researchers in different laboratories expanded the applications of X-rays (Sardinha, 1974, Schweingruber et al. 1978, Amaral and Tomazello Fo 1994, among others). Despite extensive literature on the application of the X-ray densitometry for wood analysis the information on eucalypts is very limited. The results of the wood analyses of different eucalypt species have been published largely by few authors in Brazil, Portugal, and Australia (Nicholls and Griffin 1978, Nicholls and Matheson 1980, Jorge 1994, Bucur et al. 1994, Lausberg et al. 1995, Evans and Downes 1995, Tomazello et al. 1995, Oliveira 1997, Silva 2002, Wimmer et al. 2002, Silva et al. 2004, Alzate 2004, Moya et al. 2005, Benjamin 2006, Tomazello 2006). 


\section{The methodology of wood X-ray densitometry in Eucalyptus spp}

Preparation of wood samples. The wood samples for densitometric analyses can be obtained destructively (harvesting the trees and cutting wood cross-sections) or nondestructively (mechanical extraction with an increment borer). In wood cross-sections, diametrical samples were demarcated and cut ( $20 \times 10 \mathrm{~mm}$, width $\times$ height) and placed in a supporting fixture; in the same procedure, wood cores from nondestructive samples were similarly supported, with the fibers in the horizontal direction. The samples were cut in the transverse orientation ( $2.0 \mathrm{~mm}$ thickness) with double circular saws. The thin wood samples were stored in a conditioning chamber $\left(12 \mathrm{~h}, 20^{\circ} \mathrm{C}, 50 \% \mathrm{RH}\right)$ until reaching $12 \%$ moisture content (Figure 1).

Obtaining the wood radiographic films. The wood samples and a calibration wedge of cellulose acetate (density: $1.48 \mathrm{~g} / \mathrm{cm}^{3}$ ) were placed on an X-ray film (Kodak, Diagnostic Film T-Mat, 240 x $180 \mathrm{~mm}$ ) in darkroom conditions. They were then transferred to the X-ray equipment (Hewlett Packard, Faxitron $43805 \mathrm{~N} ; 1.20 \mathrm{~m}$ distance from source to X-ray-film) and X-rayed (5 min exposure, $16 \mathrm{kV}$ accelerating voltage, $3 \mathrm{~mA}$ heating current of the cathode). The radiographic film was read with a Macrotec MX-2 (Amaral and Tomazello 1998).

Analysis of the wood radiographic films. The radiographic films were digitalized with a scanner (Hewlett Packard ScanJet 6100C/T) to a resolution of 1000 dpi (pixels/in.) with a gray scale of 256 degrees. In the digitalized image, comparisons were made of the gray scale of the wood samples and the calibration wedge, and the density values were converted into a file (DEN), using CRAD software. In this sequence, the file DEN was read with aid of the software CERD considering $500 \times 10 \mu \mathrm{m}$ (length $\mathrm{x}$ width) density measurements for segments of $25 \%$ of the length of the wood samples.

Wood density radial profile. The analyses of the wood samples generated a file containing the values of wood density and the respective corresponding wood density profiles of the eucalypt trees (Mothe et al. 1998). Using the wood density profile it is possible to calculate other parameters, such as mean, maximum, and minimum densities.

\section{The X-ray technique in nondestructive evaluation of eucalypt wood}

\subsection{Wood decay detection of eucalypts through X-ray densitometry}

Despite the common usage of wood in construction and structures, it has the disadvantage of biodegradation by fungi. The mycelium of the fungi can decompose the wood internally, forming discreet stains or spots of different sizes that are difficult to detect by external examination. For this condition, nondestructive methods have been recommended for the analysis of the interior of the wood using radiographic images. More recently, with the development of equipment and methods of analysis of digital images of radiographic films, it has been possible to determine the variations of the apparent density values of affected and healthy wood (Amaral and Tomazello 1998).

Species and wood sample collections. For X-ray densitometry analysis, 4 diametrical wood samples were collected at the DBH of 8-year-old Eucalyptus grandis $x$ urophylla having normal wood and areas infected by white rot fungi. Also, wood microslides of the healthy and affected areas were cut with a sliding microtome, stained with safranin and picroanilin, and observed under a microscope (Tomazello 1998). 


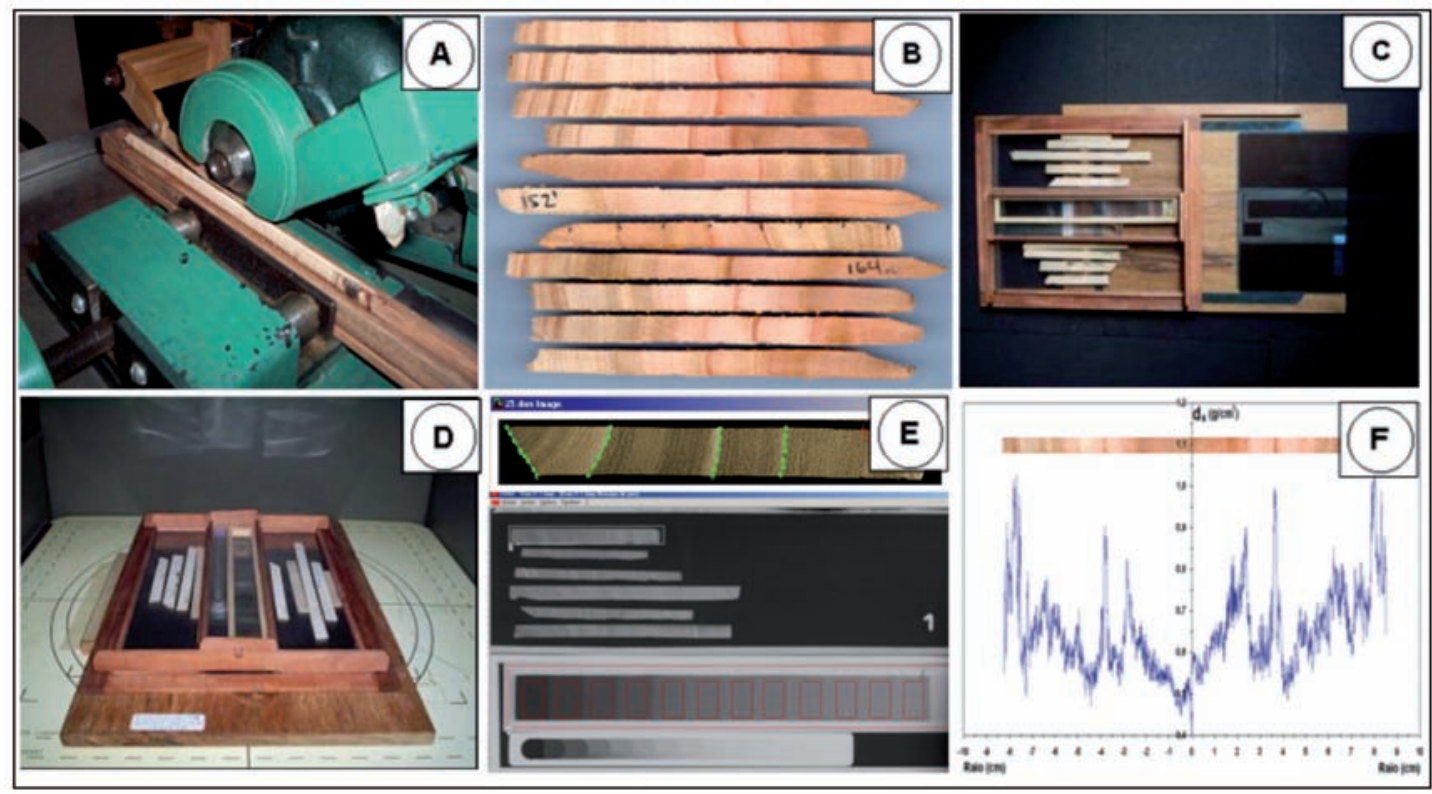

Figure 1: X-ray methodology and eucalypt wood radiographs: (a) wood samples are supported and cross-sections are cut with double parallel circular saws; (b) wood cross-sections; (c) wood samples and cellulose acetate wedge on radiographic film; (d) irradiation of the wood samples in X-ray equipment; (e) wood radiographic image and analysis in CRAD and CERD programs; (f) double-radial (bark-bark) wood density profile and respective wood cross-section.

Results. In the cross-sections of sapwood there were limited areas of whitish color and porous appearance that formed discreet stains or spots, characteristic of white rot fungi decomposition. The effect of the action of these fungi can be clearly observed in the wood density profiles of the eucalypt wood sample No. 92 (Figure 2). In the total eucalypt wood samples analyzed the mean wood density of the healthy vs. the affected areas was reduced from 0.71 to $0.59 \mathrm{~g} / \mathrm{cm}^{3}$; the maximum and minimum wood densities varied from 0.95 to 0.83 and 0.57 to $0.44 \mathrm{~g} / \mathrm{cm}^{3}$, respectively. The reduction of wood density (17-23\%) resulted from the white rot fungi decomposition of the wood cell wall constituents, lignin, cellulose, and hemicelluloses. Applying the similar methodology, Bucur et al. (1997) observed a reduction in wood density of $25 \%$ in the Fagus silvatica with white rot (Trametes versicolor) and of $18 \%$ in Pinus sylvestris with brown rot (Gloeophyllum trabeum) after long time of exposure (5 months of incubation) under laboratory conditions. The wood becomes more permeable and hygroscopic due to the anatomicalchemistry alterations of the cell wall components and the destruction of the pit membranes, resulting in drastically affected mechanical properties of wood (Wilcox 1973, Oliveira 1986, Eaton and Hale 1993). In the advanced phases of fungal attack, the presence of holes and a reduction of the thickness of secondary cell wall (beginning at the interface of the S3 layer) are observed. The vessels of some hardwood species are slightly affected; the cell wall corners and middle lamella have greater resistance to the biodegradation and are degraded only in the final stages of the wood decomposition (Figure 3). 


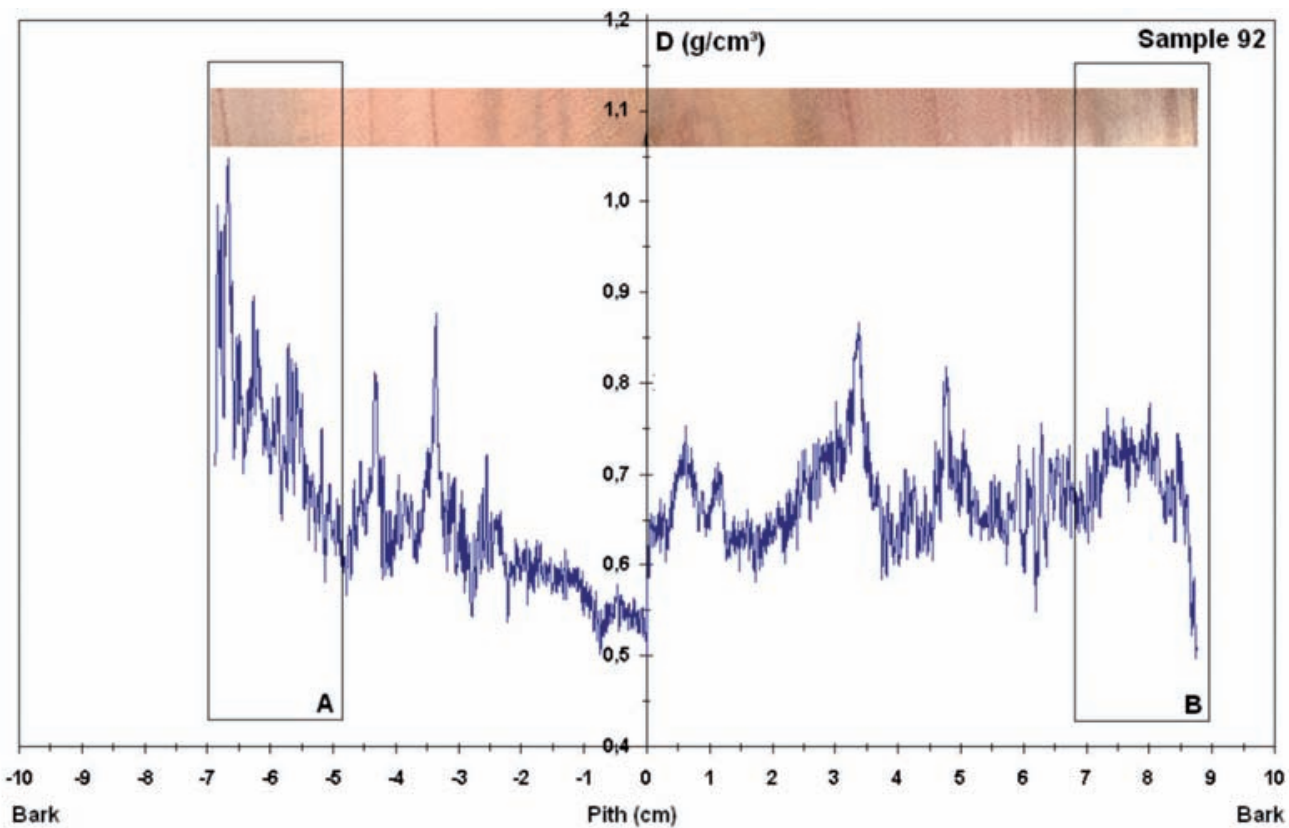

Figure 2: Wood density profile (sample 92) of Eucalyptus grandis $\mathrm{x}$ urophylla. A -healthy and B - affected area of white rot fungi.

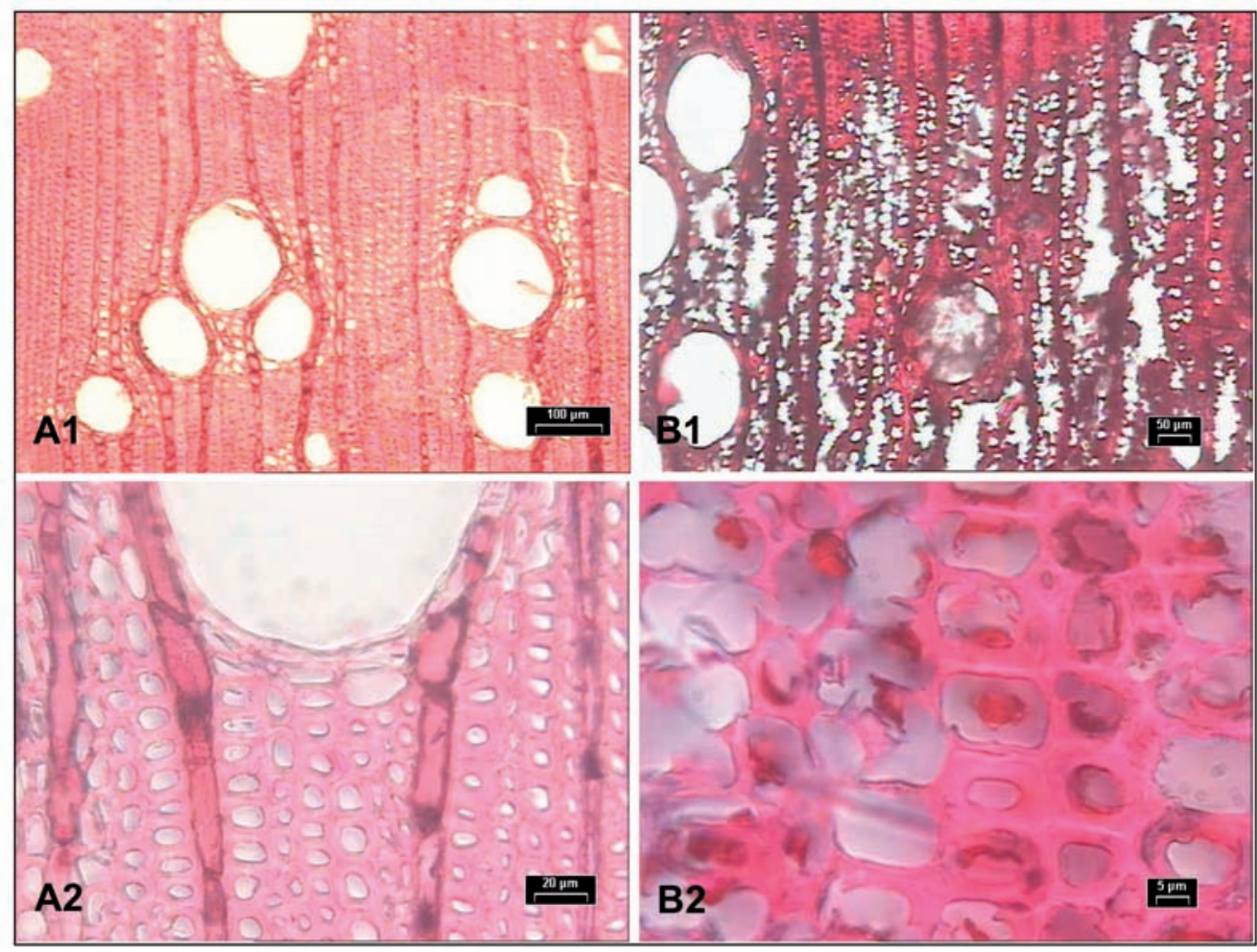

Figure 3: Wood microscopic features of Eucalyptus grandis $x$ urophylla. A1,2- healthy; and B1,2 - affected area of white rot fungi. 


\subsection{Sapwood-heartwood of Corymbia citriodora by the X-ray densitometry}

The visual separation of heartwood and sapwood for some species is very difficult due to little contrast in color. The presence and amount of heartwood-sapwood in eucalypt trees alters the wood technological properties and applications, like solid wood, pulp and paper, panels, particleboard, etc. (Bamber and Fukazawa 1985). In these species the application of X-ray densitometry can be extremely useful to identify the sapwood-heartwood boundaries, based on different wood properties and levels of X-ray attenuation.

Species and wood sample collections. For X-ray densitometry analysis, 6 wood samples were collected at the DBH of 29-year-old Corymbia citriodora. Wood samples (10 x $10 \times 10 \mathrm{~mm})$ were obtained from sapwood and heartwood, and the cross-sections were polished using a sliding microtome for microscopic examination of the tyloses (Tomazello 1998).

Results. In the wood cross-sections, sapwood and heartwood were examined in the X-ray wood density profile of the sample No. 6 (Figure 4). The mean wood density of the heartwood is significant greater (ANOVA, $5 \%$ level) than the sapwood, $1.31 \mathrm{vs} .1 .14 \mathrm{~g} / \mathrm{cm}^{3}$. Likewise the maximum and minimum wood densities were 1.48 vs. 1.34 and 1.11 vs. $0.91 \mathrm{~g} / \mathrm{cm}^{3}$, respectively, with significant differences (ANOVA, $5 \%$ level to minimum wood density) (Table 1). The wood density increase results from the tyloses development in the lumen of vessels, as well as the deposition of heartwood substances (tannins, oils, etc.) in the radial parenchyma cells. The heartwood becomes darker, with lower permeability and higher natural resistance against microorganisms. There is greater attenuation of X-rays in the heartwood from the xylem cells containing tyloses and chemical components; whereas the sapwood lower density is a result of functional xylem with open vessels.

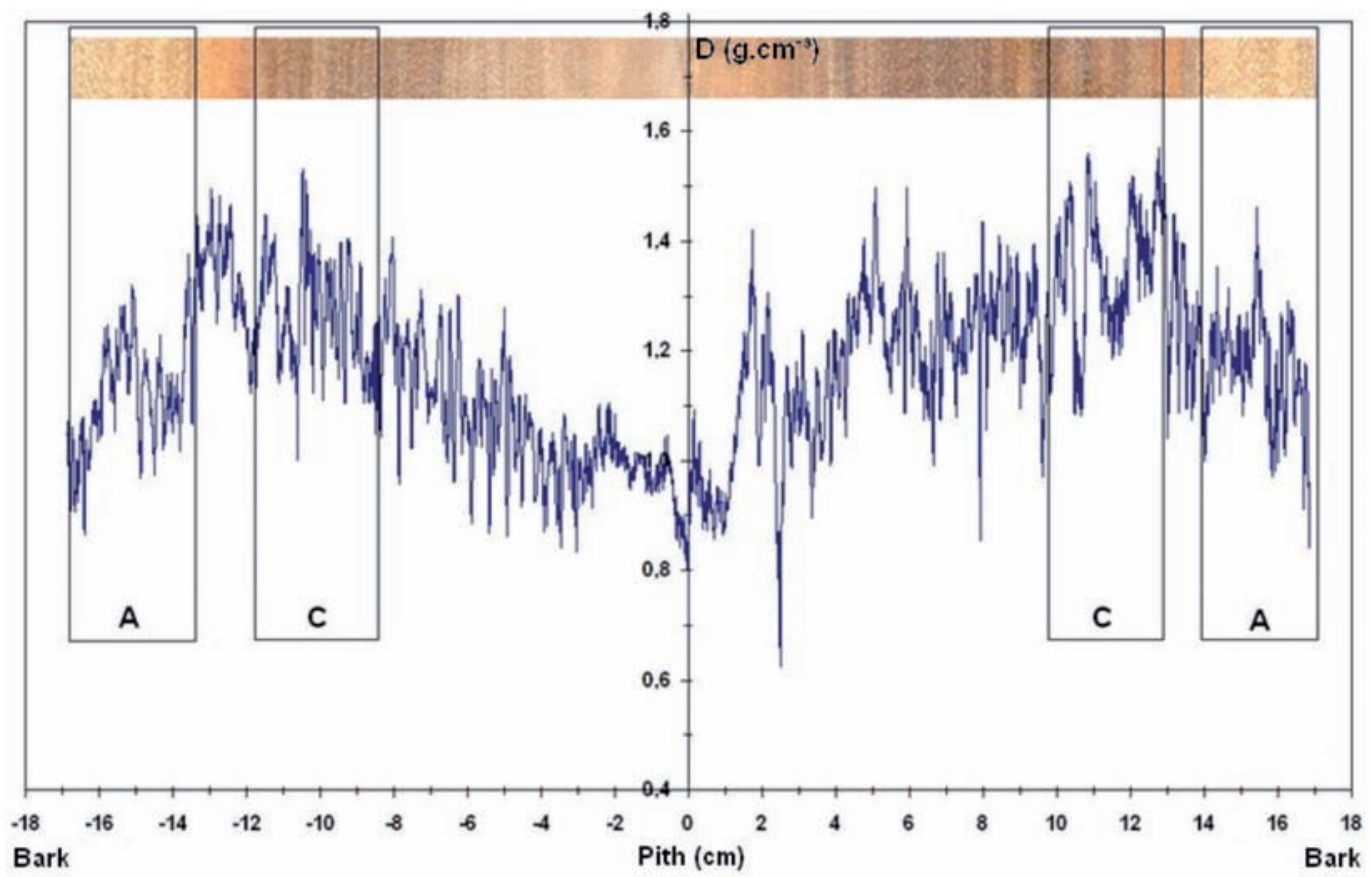

Figure 4: Wood density profile of sample No. 6 of Corymbia citriodora. A - sapwood and C - heartwood areas. 
Table 1: Wood density of sapwood (A) and of heartwood (B) of Corymbia citriodora.

\begin{tabular}{|c|c|c|c|c|c|c|c|}
\hline \multirow{3}{*}{ Sample } & \multirow{3}{*}{ Radio } & \multicolumn{6}{|c|}{ Wood density $\left({\left.\mathrm{g} . \mathrm{cm}^{-3}\right)}^{-3}\right.$} \\
\hline & & \multicolumn{2}{|c|}{$D_{\text {average }}$} & \multicolumn{2}{|c|}{$D_{\text {maximum }}$} & \multicolumn{2}{|c|}{$D_{\text {minimum }}$} \\
\hline & & $\mathrm{H}$ & $\mathbf{s}$ & $\mathrm{H}$ & s & $\mathrm{H}$ & $\mathbf{s}$ \\
\hline \multirow[t]{2}{*}{1} & $\mathbf{R}$ & 1.18 & 1.07 & 1.32 & 1.19 & 1.07 & 0.94 \\
\hline & $\mathbf{L}$ & 1.37 & 1.21 & 1.54 & 1.43 & 1.19 & 1.01 \\
\hline \multirow[t]{2}{*}{2} & $\mathbf{R}$ & 1.38 & 1.16 & 1.55 & 1.41 & 1.23 & 0.89 \\
\hline & $\mathbf{L}$ & 1.25 & 1.11 & 1.35 & 1.24 & 1.15 & 0.91 \\
\hline \multirow[t]{2}{*}{3} & $\mathbf{R}$ & 1.36 & 1.18 & 1.57 & 1.46 & 1.04 & 0.84 \\
\hline & $\mathbf{L}$ & 1.29 & 1.11 & 1.53 & 1.32 & 1,00 & 0.87 \\
\hline Stand. Dev. & & 0.08 & 0.05 & 0.11 & 0.11 & 0.09 & 0.06 \\
\hline Mean & & $1.31 \mathrm{a}$ & $1.14 \mathrm{~b}$ & $1.48 \mathrm{a}$ & $1.34 \mathrm{a}$ & $1.11 \mathrm{a}$ & $0.91 b$ \\
\hline
\end{tabular}

$\mathrm{R}$ (right) and L (left) radius orientation; $\mathrm{H}$ (heartwood) and $\mathrm{S}$ (sapwood) of wood samples. Mean values followed by the same letter are not significantly different at the $5 \%$ level

\subsection{Eucalypt management and evaluation of wood quality by X-ray densitometry}

The Brazilian eucalypt forest plantations have been treated experimentally to induce higher wood productivity. The results of experimental areas indicate a volume of $34 \mathrm{~m} / \mathrm{ha} / \mathrm{yr}$ (without fertilization) to $49 \mathrm{~m}^{3} / \mathrm{ha} / \mathrm{yr}$ (with fertilization) and as high as $51 \mathrm{~m}^{3} / \mathrm{ha} / \mathrm{yr}$ (extreme fertilization); irrigated plantations have produced from $63 \mathrm{~m}^{3} / \mathrm{ha} / \mathrm{yr}$ to $68 \mathrm{~m}^{3} / \mathrm{ha} / \mathrm{yr}$, when fertilization has been added. However, it is important to evaluate the wood properties even though the main objective is to increase the wood volume (Raymond and Muneri 1998, Beadle et al. 2001) through appropriate techniques such as X-ray densitometry (Tomazello 2006).

Species and wood sample collections. For X-ray densitometry analysis, 30 diametrical wood samples were collected at the DBH of 7.11-year-old Eucalyptus grandis $x$ urophylla, exposed to the treatments: control $(\mathrm{CN})$, irrigation (CI), and fertilization/irrigation (FI), following a period of 3.1 years of common forest management applied to all trees.

Results. The wood density profiles of the samples of eucalyptus trees having the three treatments $(\mathrm{CN}$, CI, FI) are presented in Figure 5 and Table 2. Initially, the total radial length of the samples was 6.5, 8.5-9.5, and $9.0 \mathrm{~cm}$ for CN, CI, and FI, respectively, showing significant differences (ANOVA $5 \%$ level) of the irrigated and fertilized/irrigated to the control. The increase of the external diameter of the eucalypt trunks exposed to fertilization/irrigation has been shown for a few eucalyptus species and sites (Beadle et al. 1997, 2001, Raymond 1998), as a result of stimulating the cambium from supplementary addition of water and nutrients in the soil. However, the wood density profile makes it possible to verify and quantify important and significant responses of the trees to each treatment: the second tree-ring from the pith (indicated by the arrows) delimitated an internal wood core formed before the application of the treatments and common to all the eucalypt trees. The internal wood core of the eucalypt stems, with $4.0-4.5 \mathrm{~cm}$ radius, formed before the application of the treatments, presented the mean wood density of $0.61,0.63$, and $0.60 \mathrm{~g} / \mathrm{cm}^{3}$ to the treatments $\mathrm{CN}, \mathrm{CI}$, and FI, respectively, with no significant differences 
(ANOVA 5\% level). The external core of the eucalypt stems formed after the application of the treatments presented 2.8, 4.0, and $4.3 \mathrm{~cm}$ lengths in CN, CI, and FI, respectively. The external core of eucalypt stems has characteristic variations of wood density, in addition to the differentiated radial length. For the $\mathrm{CN}$ treatment, the wood density has significant variability, higher values of wood density (significant difference, ANOVA 5\% level), and formation of several growth layers; in CI and FI, the wood density has smaller value and variability and with 2-3 growth layers. Analyzing the wood density profile of $E$. grandis $x$ urophylla verified similarities with the literature: smaller values of wood density in the stem central region, with progressive increases in direction to the bark; oscillations of the density values in the pith-bark direction due to (i) vessels of larger diameter and (ii) layers of thickened cell wall fibers and smaller vessel diameters, with similarities for the same hybrid (Alzate 2004).

Table 2: Wood density of Eucalyptus grandis x urophylla trees in relation to the period of the treatments application.

\begin{tabular}{|c|c|c|c|}
\hline \multirow{2}{*}{ Treatment } & \multicolumn{3}{|c|}{ Wood density $\left({\left.\mathrm{g} . \mathrm{cm}^{-3}\right)}^{-3}\right.$} \\
\hline & Mean & Minimum & Maximum \\
\hline & \multicolumn{3}{|c|}{ Total treatments } \\
\hline $1 \mathrm{CN}$ & 0.66 a $(0.01)$ & 0.48 a $(0.02)$ & 1.07 a $(0.05)$ \\
\hline $2 \mathrm{CI}$ & 0.66 a $(0.02)$ & $0.52 \mathbf{b}(0.02)$ & $1.06 \mathrm{a}(0.05)$ \\
\hline \multirow[t]{2}{*}{$3 \mathrm{FI}$} & $0.63 \mathbf{b}(0.03)$ & 0.46 a $(0.04)$ & 0.97 b $(0.08)$ \\
\hline & \multicolumn{3}{|c|}{ Before Treatments } \\
\hline $1 \mathrm{CN}$ & 0.61 a $(0.02)$ & 0.49 a $(0.02)$ & $1.02 \mathrm{a}(0.08)$ \\
\hline $2 \mathrm{CI}$ & 0.63 a $(0.02)$ & $0.52 \mathbf{b}(0.02)$ & $1.02 \mathrm{a}(0.08)$ \\
\hline \multirow[t]{2}{*}{$3 \mathrm{FI}$} & $0.60 \mathrm{a}(0.05)$ & $0.47 \mathrm{a}(0.04)$ & 0.93 b $(0.09)$ \\
\hline & \multicolumn{3}{|c|}{ After treatments } \\
\hline $1 \mathrm{CN}$ & 0.72 a $(0.03)$ & $0.55 \mathrm{a}(0.03)$ & $1.06 \mathbf{a}(0.06)$ \\
\hline $2 \mathrm{CI}$ & $0.69 \mathrm{ab}(0.03)$ & $0.54 \mathbf{a}(0.04)$ & $0.99 \mathbf{a b}(0.07)$ \\
\hline $3 \mathrm{FI}$ & $0.65 \mathbf{b}(0.05)$ & 0.49 b $(0.05)$ & 0.93 b $(0.10)$ \\
\hline
\end{tabular}

$\mathrm{CN}$ : control; CI: irrigated; FI: fertilized and irrigated eucalypt trees. Mean values followed by the same letter are not significantly different at the $5 \%$ level 


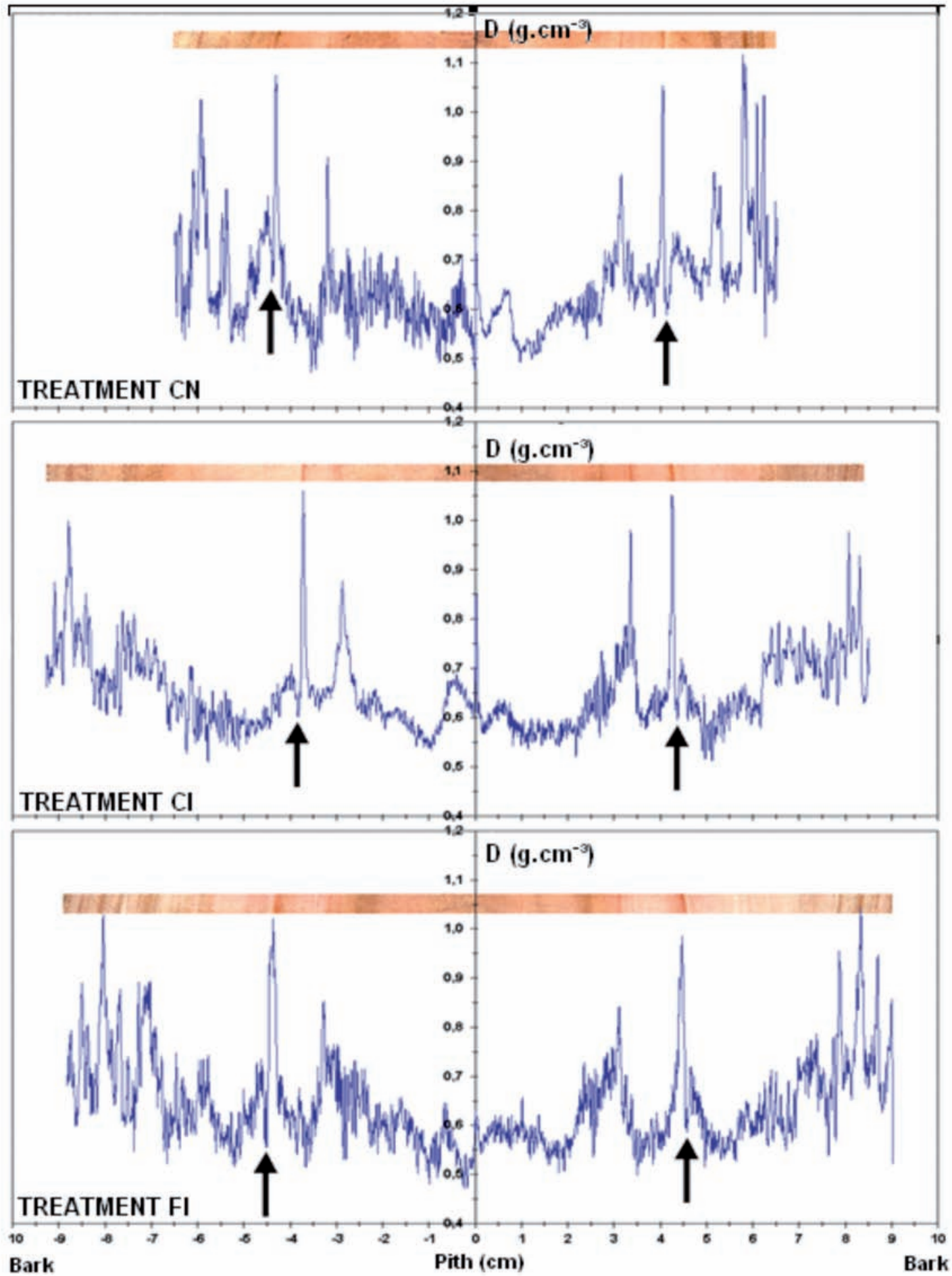

Figure 5: Wood density profiles of samples No. 22, 17, and 12 of Eucalyptus grandis $x$ urophylla, having treatments $\mathrm{CN}, \mathrm{CI}$, and FI, respectively. Arrows indicate the beginning the treatments in all the trees with 3.1 years; trees were harvested at 7.11 years. 


\section{CONCLUSIONS}

The decay of eucalypt wood by white rot fungi can be detected by X-ray densitometry as shown by a decrease in the mean, minimum, and maximum wood density. The reduction of wood density is from the biodegradation of cell wall components by the mycelium of white rot fungi.

The X-ray densitometry permits differentiation of sapwood and heartwood of eucalypts due to differences in anatomical structure and chemical composition. These differences in sapwood and heartwood are reflected in the attenuation of X-rays because of the variations in wood density.

X-ray densitometry of the wood density profile made it possible to detect the response of eucalypts exposed to different management treatments: control, irrigation, and fertilization/irrigation.

\section{ACKNOWLEDGMENTS}

We would like to thank Dr. Frank C. Beall, University of California at Berkeley, Richmond, USA, and a anonymous reviewer for providing a constructive comments and suggestions on an early version of this manuscript.

\section{REFERENCES}

Alzate, S.B.A. 2004. Caracterização da madeira de árvores de clones de Eucalyptus grandis, E. saligna e E. grandis $x$ urophylla. Tese Doutorado. Universidade de São Paulo, São Paulo.

Amaral, A.C.B.; Tomazello, M. 1998. Avaliação das características dos anéis de crescimento de Pinus sp através da densitometria de raios X. Revista Ciência e Tecnologia 11/12 (6):17-23.

Bamber, R.K.; Fukazawa, K. 1985. Sapwood and heartwood: a review. Forestry Abstract 46(9): 567-580.

Beadle, C.; Banham, P.; Worledge, D.; Russell, S.L.; Hetherington, S. J.; Honeysett, J.L.; White D.A. 2001. Irrigation increases growth and improves fibre quality of Eucalyptus globulus and E. nitens. In. IUFRO Conference on Silviculture and Improvement of Eucalyptus. Salvador, Brasil. Proceedings. Colombo, Paraná.

Beadle, C.; Banham, P.; Worledge, D.; Russell, S.L.; Hetherington, S. J.; Honeysett, J.L.; White, D.A. 2001. Effect of irrigation on growth and fibre quality of Eucalytpus globulus and Eucalyptus nitens. Appita Journal 54(2):144-147.

Benjamin, C.A. 2006. Estudo da estrutura anatômica e das propriedades físico-mecânicas da madeira de Corymbia (Eucalyptus) citriodora. Tese Doutorado. Universidade Estadual Paulista Julio de Mesquita Filho, São Paulo, Brasil.

Bucur, V.; Herbe, C.; Nosei, G. 1994. Annual rig characteristics of Pinus taeda measured by ultrasonic and X-ray techniques. IAWA Journal 15(2):121-132.

Bucur, V.; Garros, S.; Navarrete, A.; Troya, M.T.; Guyonnet, R. 1997. Kinetics of wood degradation by fungi with X-ray microdensitometry technique. Wood Science and Technology 31:383-389.

Eaton, R.A.; Hale, M.D.C. 1993. Wood decay, pest and protection. London: Chapman\&Hall.

Evans. R.; Downes, G. 1995. Recent developments in automated wood quality assessment. In. Eucalypt Plantation: improving fibre yield and quality. In. IUFRO Congress. Hobart. Australia. 
Fischer, R.C.; Tasker, H.S. 1940. The detection of wood boring insects by means of X-rays. Annals Applied Biology 27(1):92-100.

Jacquiot, C. 1961. L'utilization des rayons X dans les recherches et les essais sur les insectes xylophages. Corrosion et antiocorrosion 9(3):71-79.

Jorge, M.F. 1994. Variabilidade anatômica, física e química da madeira de Eucalyptus globulus. Tese Doutorado. Universidade Técnica de Lisboa. ISA. Lisboa, Portugal.

Keller, R. 1968. Des characteristics nouvelles por l'étude dês propriétés mecániques dês bois: les composantes de la densité. Annales des Sciences Forestieres 25(4):3237-3239.

Lausberg, M.J.F.; Gilchrist, K.F.; Skipwith, J.H. 1995. Wood properties of Eucalyptus nitens grown in New Zealand. New Zealand Journal of Forestry Science 25(2):147-163.

Lenz, O. 1957. L'utilization de la radiographie pour l'examen des couches d'accroissement. Mitteilungen 33(5):15-23.

Legrand, C. 1946. Sur quelques applications des rayons Xá l'étude des bois et leurs derives. In. Congrès International pour l'Explotation et l'Utilization Rationelles du Bois. Paris. France. 29-31p.

Mothe, F.; Duchanois, G.; Zannier, B.; Leban, J.M. 1998. Microdensitometric analysis of wood samples: data computation method used at Inra-ERQB (Cerd Program). Annales des Sciences Forestieres, 55(3):301-313.

Moya, R.R.; Zarate, B.A.; Tomazello Filho, M. 2005. La utilización de la densitometría de rayos $\mathrm{X}$ para establecer la variabilidad de la densidad de la madera proveniente de plantaciones de rápido crecimiento en América Latina. In. Reunión sobre Investigación y Desarrollo de Productos Forestales, 10., Concepción. Chile.

Nicholls, J.W.P.; Griffin, A.R. 1978. Variation in wood characteristics in field trial of Eucalyptus obliqua, E. regans and some intermediate forms. Australian Forestry Research 8:93-102.

Nicholls, J.W.P.; Matheson, A.C. 1980. Variation in wood characteristics in thinning from field trial of Eucalyptus obliqua. Australian Forestry Research 10:239-247.

Oliveira, A.M.F.; Lelis, A.T.; Lepage, E.S. 1986. Agentes destruidores da madeira. In: Lepage, E.S. (coord.). Manual de preservação de madeiras. São Paulo: IPT.

Oliveira, J.T.S. 1997. Caracterização da madeira de eucalipto para a construção civil. Tese Doutorado. Escola Politécnica, Universidade de São Paulo, São Paulo.

Parker, M.L. 1971. Dendrochronological techniques used by the Geological Survey of Canadá. In: Geological Survey of Canada Bulletin, 1-71 p.

Polge, H. 1963. Une nouvelle méthode de détermination de la texture du bois: l'analyse densitométrique de clichés radiographiques. Annales des Sciences Forestieres20(4):531-581.

Raymond, C.A. 1998. Wood properties, silviculture and growth: a review of published literature for eucalypts. Cooperative Research Centre for Sustainable Production Forestry Technical Report No. 6.

Raymond, C.A.; Muneri, A. 2000. Effect of fertilizer on wood properties of Eucalyptus globulus. 
Canadian Journal of Forestry Research 30:136-144.

Sardinha, R.M.A. 1974. Variation in density and some structural features os wood from Eucalyptus saligna from Angola. Thesis, $\mathrm{PhD}$. Oxford University. $354 \mathrm{p}$.

Silva, J.C. 2002. Caracterização da madeira de Eucalyptus grandis de diferentes idades visando sua utilização na indústria moveleira. Tese Doutorado. Universidade Federal do Paraná, Curitiba, Paraná.

Silva, J.C.; Oliveira, J.T.; Tomazello Fo, M.; Keinert, S.; Monteiro, J.L. 2004. Influencia da idade e da posição radial na massa especifica da madeira de Eucalyptus grandis. Revista Floresta 34(1):13-22.

Schweingruber, F.; Fritts, H.C.; Braker, O.U.; Drew, L.G.; Schar, E. 1978. The X-ray technique as applied to dendroclimatology. Tree-Ring Bulletin 38:61-91.

Tomazello Fo, M.; Schweingruber, F.; Schar, E. 1995. Wood anatomical and X ray densitometric analysis of Eucalyptus grandis and E. saligna. In. International Symposium on Tree Anatomy and Wood Formation. Tiajin, China.

Tomazello Fo, M 1998. Práticas de anatomia e identificação de madeiras. Apostilado. ESALQ/ Universidade de São Paulo.

Tomazello Fo, M. 2006. Efeito da irrigação e da fertilização nas propriedades do lenho de árvores de Eucalyptus grandis x urophylla. Tese Livre Docência. Universidade de São Paulo, São Paulo, Brasil.

Wilcox, W.W. 1973. Degradation in relation to wood structure. In: Nicholas, D.D. (ed.) Wood deterioration and its prevention by preservative treatments - Degradation and protection of wood. $1^{\text {a }}$ ed. Syracuse, New York: Syracuse University Press.

Wimmer, R.; Downes, GM.; Evans, R. 2002. High-resolution analysis of radial growth and wood density in Eucalyptus nitens, grown under different irrigation regimes. Annals of Forest Sciences 59:519-524.

Worschitz, F. 1932. L'utilization des rayos X en vue de l'etude de la qualité du bois. In. Congrès IUFRO. Paris. France. 459-489 p. 
